УДК $911.52(292.471)$

\title{
АНАЛИЗ АБСОЛЮТНЫХ ВЫСОТ РЕЛЬЕФА В ПРЕДЕЛАХ ЛАНДШАФТОВ КРЫМСКОГО ПОЛУОСТРОВА
}

Табунщик В. А., Келип А. А., Андрончик Я. О.

ФГБУН ФИЦ «Институт биологии южных морей имени А. О. Ковалевского РАН»,

2. Севастополь, Российская Федерация,

e-mail: tabunshchyk@ya.ru

В статье получены количественные данные об абсолютной высоте рельефа в пределах таксономических единиц ландшафтов Крымского полуострова — ландшафтных уровней, ландшафтных зон, ландшафтных поясов и ярусов, а также групп местностей. Установлено, что значение абсолютной высоты рельефа является фактором, оказывающим большое влияние на дифференциацию ландшафтов Крымского полуострова на уровне высоких таксономических единиц. Постепенно влияние этого фактора сглаживается при выделении более мелких таксономических единиц.

Ключевые слова: ландшафт, Крым, Крымский полуостров, рельеф, высота, абсолютная высота, фактор.

\section{Введение}

Характеристика рельефа территории является одним из важнейших факторов, влияющих на формирование и развитие ландшафтов [Рельеф и ландшафты, 1977; Структурнорегиональный ... , 1984; Вопросы истории ... , 1976; Плюснин, 2003; Мурашова, 2013; Исаченко, 1991]. Уже в первых работах по выделению ландшафтов подчёркивалась важность рельефа. Л. С. Берг уже в 1915 г. [Берг, 1915, С. 471] указывает на рельеф как на один из факторов, формирующих ландшафт: «Природный ландшафт есть область, в которой характер рельефа, климата, растительного и почвенного покрова сливается в единое гармоническое целое, типически повторяющееся на протяжении известной зоны земли». Н. А. Солнцев говорит, что географическим ландшафтом следует называть «генетически однородную территорию, на которой наблюдается закономерное и типическое повторение одних и тех же взаимосвязанных сочетаний: геологического строения, форм рельефа, поверхностных и подземных вод, микроклиматов, почвенных разностей, фито- и зооценозов» [Солнцев, 2001]. Г. Н. Анненская с соавторами в работе [Морфологическая структура ... , 1962, С. 9] пишет, что «ландшафт это генетически однородный природный территориальный комплекс, имеющий одинаковый геологический фундамент, один тип рельефа, одинаковый климат и состоящий из свойственного только данному ландшафту набора динамически сопряжённых и закономерно повторяющихся в пространстве основных и второстепенных урочищ». Таким образом, большинство авторов, даже представляющих различные научные школы ландшафтоведения, указывают, что на дифференциацию и функционирование ландшафтов оказывает влияние большое количество факторов, один из которых - рельеф.

Однако в большинстве случаев рельеф той или иной территории описывается качественными характеристиками и при этом игнорируется большой пласт количественной информации о рельефе территории, который может быть проанализирован и таким образом могут быть установлены связи рельефа с существованием ландшафтов. Одной их таких характеристик рельефа является абсолютная высота местности. Знание точных характеристик рельефа представляется крайне важным для понимания свойств ландшафта в целом, закономерностей его развития, прогноза возможных изменений под воздействием природных факторов и деятельности человека [Рельеф и ландшафты, 1977; Структурно-региональный ..., 1984].

\footnotetext{
${ }^{*}$ Исследование выполнено в рамках темы НИР «Изучение пространственно-временной организации водных и сухопутных экосистем с целью развития системы оперативного мониторинга на основе данных дистанционного зондирования и ГИС-технологий», регистрационный номер 121040100327-3.
} 
Для Крымского полуострова (КП) одной из наиболее детальных и информативных ландшафтных карт является ландшафтно-топологическая карта Г. Е. Гришанкова [Современные ландшафты ..., 2009]. В ней представлены контуры и описание операционно-территориальных единиц на разных уровнях ландшафтной организации: ландшафтные уровни (ЛУ) - самый высокий таксон, ландшафтные зоны (ЛЗ), ландшафтные пояса и ландшафтные ярусы (ЛП и ЛЯ), группы местностей (ГМ).

Однако следует признать, что в данной карте характеристики рельефа представлены только качественные, например «пояс лесных и лугово-лесостепных плато» или «пояс аккумулятивных и денудационных слабодренированных равнин...». Подробных количественных данных о ландшафтах КП на карте нет, а в более поздних публикациях, основанных на работе с данной картой, такая информация неполная либо противоречивая. [Современные ландшафты ..., 2009; Позаченюк, 1999]. При этом рельеф КП достаточно подробно исследован, существуют гипсометрические карты различных масштабов.

В связи с этим целью данного исследования был количественный анализ рельефа ландшафтных единиц КП, а именно фактора «абсолютная высота, м», актуализация данных, установление связей и закономерностей между величинами абсолютной высоты рельефа и ландшафтными единицами разных таксонов в пределах КП.

\section{Материалы и методы}

Для анализа фактора рельефа «абсолютная высота, м» в пределах КП использовались данные Shuttle Radar Topography Mission (SRTM), представленные в виде растра значений высоты, и программный комплекс QGIS, в котором производилась обработка растра значений абсолютной высоты и были получены статистические данные.

Методика исследования состояла в следующем:

1. Ландшафтно-типологическая карта Г. Е. Гришанкова, опубликованная в [Современные ландшафты ... , 2009], была оцифрована и переведена в шейп-формат.

2. С помощью инструментов зональной статистики путём сопоставления пространственного положения шейп-файла ландшафтной карты и растра значений абсолютной высоты для каждого контура в пределах ландшафтной карты, а также для Крымского полуострова получены минимальные, максимальные средние значения абсолютной высоты в пределах ландшафтного контура, а также медиана значений и амплитуда (факторная амплитуда) значений.

3. Дополнительно рассчитывался показатель относительной ширины факторной амплитуды, по которому производится разграничение ландшафтов на эврифакторные (с высоким значением факторной амплитуды, более 0,6), мезофакторные (со средними значениями факторной амплитуды, 0,1-0,6) и стенофакторные (с низкими значениями факторной амплитуды, менее 0,1 ), по формуле:

$$
l(x)_{\mathrm{i}}=\frac{x_{\mathrm{imax}}-x_{\mathrm{imin}}}{X_{\max }-X_{\min }}
$$

где $l(x)_{i}$ — относительная ширина факторной амплитуды ландшафта $i$-го вида по фактору «x»;

$x_{i \max }, x_{i \min }-$ наибольшее и наименьшее значения амплитуды ландшафта $i$-го вида по фактору «x»;

$X_{\max }, X_{\min }$ - максимальное и минимальное значения фактора « $x »$ в пределах Крымского полуострова. 


\section{Результаты и обсуждение}

На территории КП значения абсолютной высоты над уровнем моря, полученные после обработки данных SRTM, колеблются от -14 (пересыхающие участки озёр, участки побережья) до 1531 м. Амплитуда значений при этом составляет 1545 м. Таким образом, эти значения выступают геоморфологической основой, на которой происходит функционирование ландшафтов. ЛУ КП по значению абсолютных высот сильно дифференцируются (таблица 1).

Таблица 1

Положение ЛУ КП в пространстве фактора «абсолютная высота, м»

\begin{tabular}{|c|c|c|c|c|c|c|c|}
\hline \multirow[b]{2}{*}{ 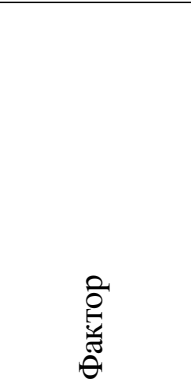 } & \multirow[b]{2}{*}{ 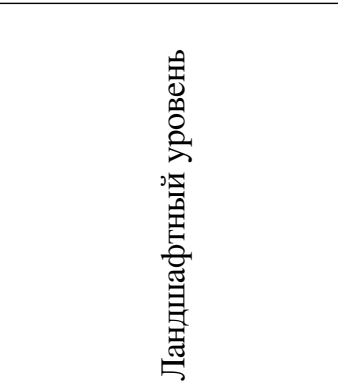 } & \multicolumn{5}{|c|}{ Значение фактора } & \multirow[b]{2}{*}{ 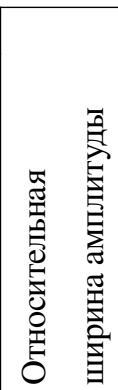 } \\
\hline & & $\sum_{\substack{\sum \\
\sum}}^{\sum}$ & 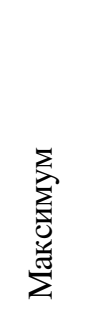 & 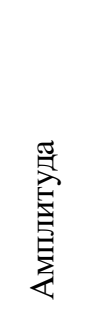 & 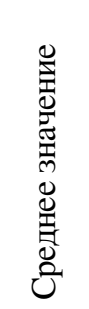 & 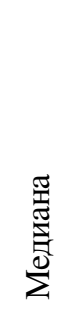 & \\
\hline \multirow{4}{*}{$\begin{array}{c}\text { Абсолютная } \\
\text { высота, м }\end{array}$} & Гидроморфный (ГЛУ) & -6 & 208 & 214 & 20,3 & 15 & 0,14 \\
\hline & Плакорный (ПЛУ) & -14 & 183 & 197 & 60,3 & 58 & 0,13 \\
\hline & Низкогорный (НЛУ) & -8 & 1047 & 1055 & 120,5 & 170 & 0,68 \\
\hline & Среднегорный (СЛУ) & 1 & 1531 & 1532 & 279,0 & 550 & 0,99 \\
\hline
\end{tabular}

Несмотря на это, наблюдается чёткая закономерность к увеличению абсолютных отметок высот, средних значений и медианы высот от ГЛУ к СЛУ. Хотя гидроморфный ЛУ занимает более низкое положение по сравнению с ПЛУ, факторная амплитуда ПЛУ немного меньше, чем у ГЛУ. Это объясняется в первую очередь сложным рельефом Керченского полуострова, на территории которого представлены отдельные фрагменты ГЛУ. Для большего понимания ситуации рассмотрим гистограммы распределения и плотность распределения абсолютных высот по каждому ЛУ (рис. 1). Из рисунка 1 следует, что каждый ландшафтный уровень в целом довольно чётко обосабливается по значениям абсолютных высот, несмотря на то что факторные амплитуды пересекаются.
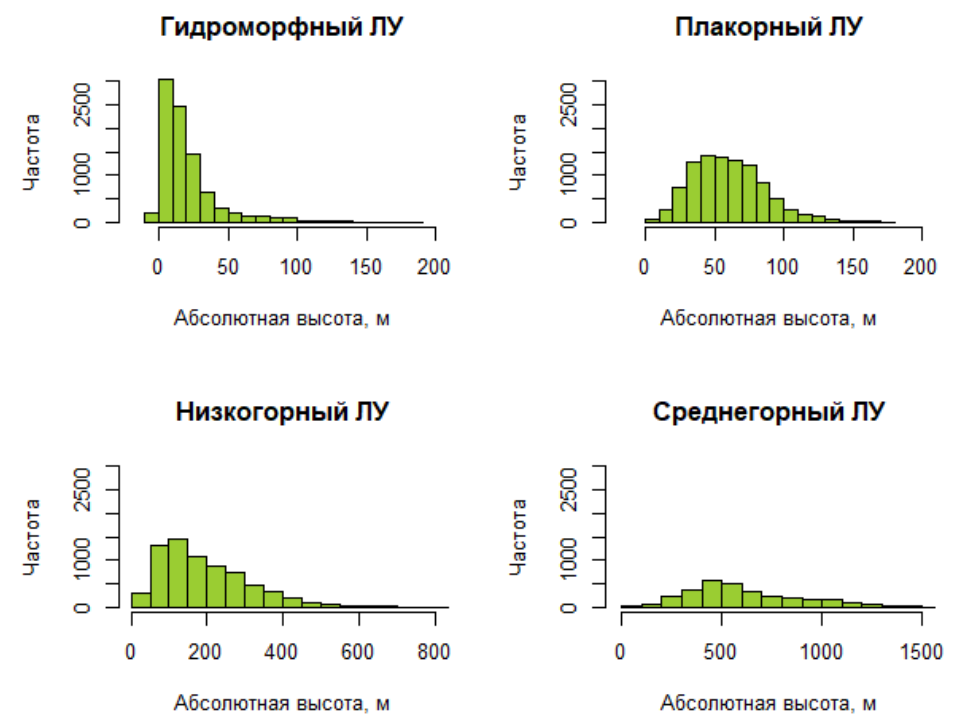

Рис. 1. Гистограммы распределения значений фактора «абсолютная высота, м» в пределах ЛУ КП 
ЛУ подразделяются на ЛЗ. Учитывая тот факт, что ГЛУ и ПЛУ состоят только из одной ЛЗ каждый, всё вышесказанное по отношению к ЛУ может быть применимо и к соответствующим ЛЗ. НЛУ и СЛУ имеют более сложное разделение на ЛЗ. В таблице 2 представлено положение ЛЗ КП в пространстве фактора «абсолютная высота, м».

Таблица 2

Положение ЛУ КП в пространстве фактора «абсолютная высота, м»

\begin{tabular}{|c|c|c|c|c|c|c|}
\hline \multirow[b]{2}{*}{ Ландшафтная зона } & \multicolumn{5}{|c|}{ Значение фактора } & \multirow[b]{2}{*}{ 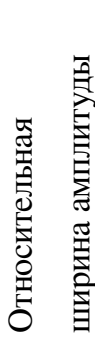 } \\
\hline & 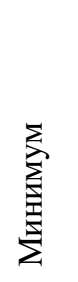 & 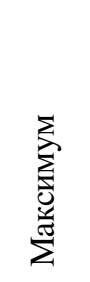 & 䍃 & 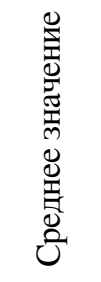 & 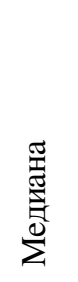 & \\
\hline \multicolumn{7}{|c|}{ Гидроморфный ландшафтный уровень } \\
\hline $\begin{array}{l}\text { Зона низменных недренированных и слабодрениро- } \\
\text { ванных аккумулятивных и денудационных равнин } \\
\text { с типчаково-ковылковыми, полынно-типчаковыми, } \\
\text { полынно-житняковыми степями в комплексе с гало- } \\
\text { фитными лугами и степями }\end{array}$ & -6 & 208 & 214 & 20,3 & 15 & 0,14 \\
\hline \multicolumn{7}{|c|}{ Плакорный ландшафтный уровень } \\
\hline $\begin{array}{l}\text { Зона типичных ковыльно-типчаковых и бедно- } \\
\text { разнотравно-ковыльно-типчаковых степей в комплексе } \\
\text { с петрофитными и кустарниковыми степями }\end{array}$ & -14 & 183 & 197 & 60,3 & 58 & 0,13 \\
\hline \multicolumn{7}{|c|}{ Низкогорный ландшафтный уровень } \\
\hline $\begin{array}{l}\text { Зона предгорных аккумулятивных, останцово- } \\
\text { денудационных и структурных денудационных } \\
\text { равнин и куэстовых возвышенностей с разнотравными } \\
\text { степями, кустарниковыми зарослями, лесостепью } \\
\text { и низкорослыми дубовыми лесами }\end{array}$ & -8 & 766 & 774 & 194,3 & 169 & 0,50 \\
\hline $\begin{array}{l}\text { Зона южного макросклона гор, полусубтропиче- } \\
\text { ских дубовых, фисташково-дубовых, можжевелово- } \\
\text { сосновых лесов и шибляковых зарослей }\end{array}$ & -2 & 1047 & 1049 & 213,9 & 176 & 0,68 \\
\hline \multicolumn{7}{|c|}{ Среднегорный ландшафтный уровень } \\
\hline $\begin{array}{l}\text { Зона северного макросклона гор, буковых, дубовых } \\
\text { и смешанных широколиственных лесов }\end{array}$ & 1 & 1500 & 1499 & 532,6 & 504 & 0,97 \\
\hline $\begin{array}{l}\text { Зона яйлинских плато, горных лугов и горной } \\
\text { лесостепи }\end{array}$ & 419 & 1531 & 1112 & 993,5 & 980 & 0,72 \\
\hline $\begin{array}{l}\text { Зона южного макросклона гор, дубовых, сосновых } \\
\text { и смешанных широколиственных лесов }\end{array}$ & 41 & 1485 & 1444 & 557,3 & 491 & 0,93 \\
\hline
\end{tabular}


В то же время на рисунке 2 представлена гистограмма распределения фактора «абсолютная высота, м» по ЛЗ.

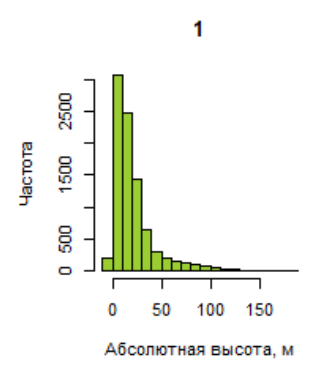

5

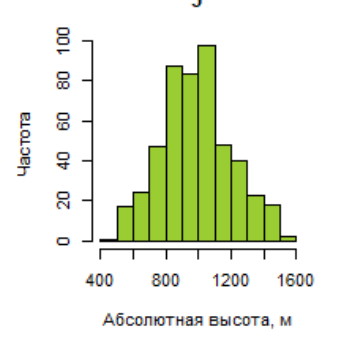

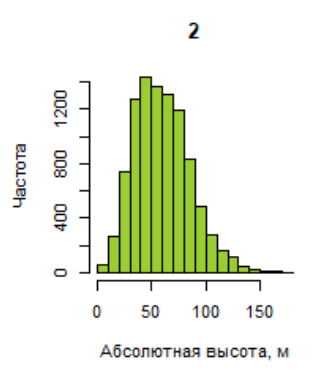

6

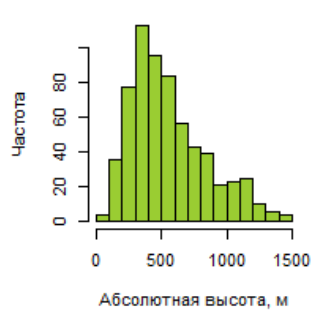

3

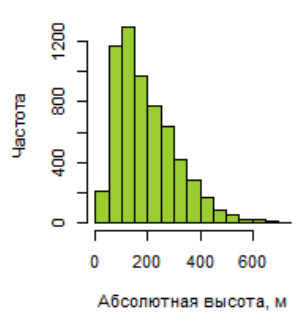

7

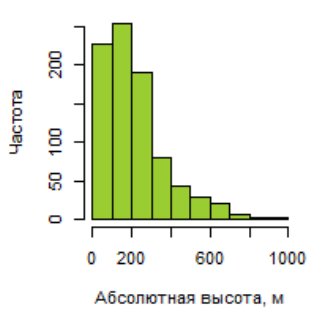

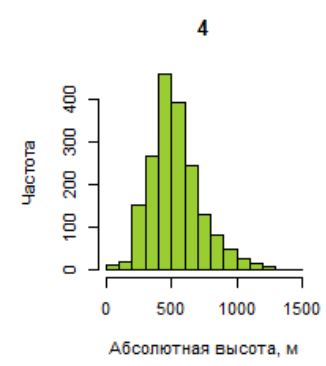

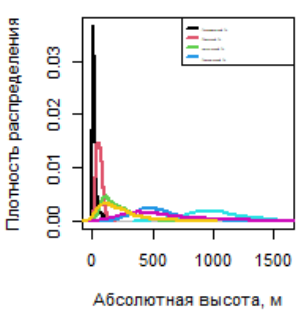

Рис. 2. Гистограммы распределения фактора «абсолютная высота, м» для ЛЗ КП (цифрами обозначены ЛЗ). ГЛУ: 1 - зона низменных недренированных и слабодренированных аккумулятивных и денудационных равнин с типчаково-ковылковыми, полынно-типчаковыми, полынно-житняковыми степями в комплексе с галофитными лугами и степями; ПЛУ: 2 - зона типичных ковыльно-типчаковых и бедно-разнотравно-ковыльно-типчаковых степей в комплексе

с петрофитными и кустарниковыми степями; НЛУ: 3 - зона предгорных аккумулятивных,

останцово-денудационных и структурных денудационных равнин и куэстовых возвышенностей с разнотравными степями, кустарниковыми зарослями, лесостепью и низкорослыми дубовыми лесами; 7 - зона южного макросклона гор, полусубтропических дубовых, фисташково-дубовых, можжевелово-сосновых лесов и шибляковых зарослей; СЛУ: 4 - зона северного макросклона гор, буковых, дубовых и смешанных широколиственных лесов; 5 - зона яйлинских плато, горных лугов и горной лесостепи; 6 - зона южного макросклона гор, дубовых, сосновых и смешанных широколиственных лесов.

ЛЗ подразделяются на ЛП / ЛЯ. Положение ЛП / ЛЯ КП в пространстве фактора «абсолютная высота, м» представлено в таблице 3.

Если рассматривать амплитуды поясов (таблица 2), составляющих ГЛУ, то отчётливо видно, что они пересекаются на значительных участках и в большинстве вариантов включают в себя друг друга. Ярусы, составляющие ПЛУ, практически не различаются по значению факторных амплитуд, однако немного дифференцируются по средним значениям. Наиболее пёстрая картина изменчивости пространственного распределения высоты характерна для НЛУ и СЛУ.

Для большинства ЛП / ЛЯ значения медианы и среднего значения отличаются на 1-7 \%, за исключением двух поясов НЛУ - низкогорного пояса дубово-фисташковых, можжевеловососновых лесов и шибляковых зарослей и низкогорного пояса сосновых, дубовых и смешанных широколиственных лесов и шибляковых зарослей (15 и $13 \%$ соответственно) и двух поясов ГЛУ — пояса прибрежных недренированных низменностей, пляжей и кос с галофитными лугами, солончаками и сообществами псаммофитов, а также пояса аккумулятивных и денудационных недренированных и слабодренированных низменностей с полынно-типчаковыми, полынножитняковыми и ковыльно-типчаковыми степями, где расхождение средних значений и медианы значений достигает 45 и $50 \%$ соответственно. Стоит отметить, что в большинстве рассматриваемых случаев средние значения превышают медиану значений по поясу и медиана более точно отражает среднюю тенденцию, так как распределение выборки асимметрично. 
Таблица 3

Положение ландшафтных поясов и ландшафтных ярусов КП в пространстве фактора «абсолютная высота, м»

\begin{tabular}{|c|c|c|c|c|c|c|}
\hline \multirow[b]{2}{*}{ Ландшафтная зона } & \multicolumn{5}{|c|}{ Значение фактора } & \multirow[b]{2}{*}{ 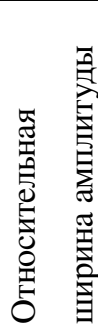 } \\
\hline & $\sum_{\sum}^{\sum_{i}^{ \pm}}$ & 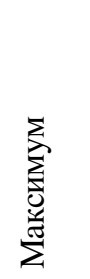 & 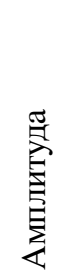 & 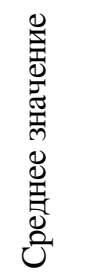 & 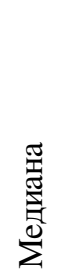 & \\
\hline \multicolumn{7}{|c|}{ Гидроморфный ландшафтный уровень } \\
\hline $\begin{array}{l}\text { Пояс прибрежных недренированных низменностей, пляжей } \\
\text { и кос с галофитными лугами, солончаками и сообществами } \\
\text { псаммофитов }\end{array}$ & -6 & 208 & 214 & 12,7 & 7 & 0,14 \\
\hline $\begin{array}{l}\text { Пояс аккумулятивных и денудационных слабодренированных } \\
\text { равнин с ковыльно-типчаковыми и полынно-типчаковыми } \\
\text { степями }\end{array}$ & -6 & 167 & 173 & 28,1 & 14 & 0,11 \\
\hline $\begin{array}{l}\text { Пояс аккумулятивных дренированных и слабодренированных } \\
\text { низменностей с ковыльно-типчаковыми степями в комплексе } \\
\text { с ковыльно-разнотравными степями }\end{array}$ & -4 & 88 & 92 & 19,6 & 18 & 0,06 \\
\hline $\begin{array}{l}\text { Пояс аккумулятивных дренированных и слабодренированных } \\
\text { низменностей с ковыльно-типчаковыми степями в комплексе } \\
\text { с ковыльно-разнотравными степями }\end{array}$ & 1 & 51 & 50 & 22,4 & 24 & 0,03 \\
\hline \multicolumn{7}{|c|}{ Плакорный ландшафтный уровень } \\
\hline $\begin{array}{l}\text { Верхний денудационный ярус ковыльно-типчаковых, петро- } \\
\text { фитных и кустарниковых степей }\end{array}$ & -2 & 183 & 185 & 72,7 & 74 & 0,12 \\
\hline $\begin{array}{l}\text { Нижний денудационно-аккумулятивный ярус с ковыльно- } \\
\text { типчаковыми, кустарниково-разнотравными и петрофитными } \\
\text { степями }\end{array}$ & -14 & 165 & 179 & 53,7 & 52 & 0,12 \\
\hline \multicolumn{7}{|c|}{ Низкогорный ландшафтный уровень } \\
\hline \multicolumn{7}{|c|}{$\begin{array}{c}\text { Зона предгорных аккумулятивных, останцово-денудационных } \\
\text { и структурных денудационных равнин и куэстовых возвышенностей с разнотравными } \\
\text { степями, кустарниковыми зарослями, лесостепью и низкорослыми дубовыми лесами }\end{array}$} \\
\hline $\begin{array}{l}\text { Пояс бородачево-разнотраных и асфоделиново-разнотравных } \\
\text { степей на аккумулятивных и денудационных равнинах }\end{array}$ & 10 & 390 & 380 & 140,0 & 128 & 0,25 \\
\hline $\begin{array}{l}\text { Пояс лесостепи на останцово-денудационных, структурных } \\
\text { денудационных и аккумулятивных равнинах, куэстовых воз- } \\
\text { вышенностях }\end{array}$ & -8 & 707 & 715 & 229,6 & 235 & 0,46 \\
\hline $\begin{array}{l}\text { Пояс дубовых лесов и кустарниковых зарослей на останцово- } \\
\text { денудационных и наклонных структурных денудационных } \\
\text { равнинах и куэстовых возвышенностях }\end{array}$ & 17 & 766 & 749 & 363,1 & 358 & 0,48 \\
\hline \multicolumn{7}{|c|}{$\begin{array}{c}\text { Зона южного макросклона гор, полусубтропических дубовых, фисташково-дубовых, } \\
\text { можжевелово-сосновых лесов и шибляковых зарослей }\end{array}$} \\
\hline $\begin{array}{l}\text { Низкогорный пояс дубово-фисташковых, } \text { можжевелово- } \\
\text { сосновых лесов и шибляковых зарослей }\end{array}$ & -2 & 648 & 650 & 160,8 & 137 & 0,42 \\
\hline $\begin{array}{l}\text { Низкогорный пояс сосновых, дубовых и смешанных широко- } \\
\text { лиственных лесов и шибляковых зарослей }\end{array}$ & 1 & 1047 & 1046 & 297,7 & 260 & 0,68 \\
\hline \multicolumn{7}{|c|}{ Среднегорный ландшафтный уровень } \\
\hline \multicolumn{7}{|c|}{ Зона северного макросклона гор, буковых, дубовых и смешанных широколиственных лесов } \\
\hline $\begin{array}{l}\text { Пояс котловин и эрозионного низкогорья, дубовых, смешан- } \\
\text { ных широколиственных и сосновых лесов }\end{array}$ & 1 & 985 & 984 & 442,6 & 441 & 0,64 \\
\hline
\end{tabular}

Продолжение на следующей странице... 


\begin{tabular}{|c|c|c|c|c|c|c|}
\hline \multirow[b]{2}{*}{ Ландшафтная зона } & \multicolumn{5}{|c|}{ Значение фактора } & \multirow[b]{2}{*}{ 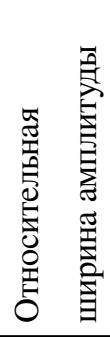 } \\
\hline & 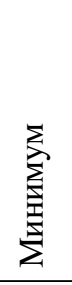 & 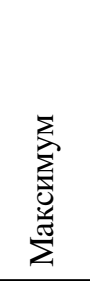 & 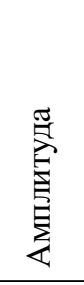 & 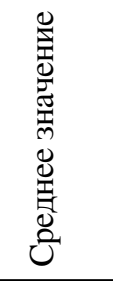 & 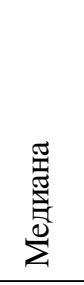 & \\
\hline $\begin{array}{l}\text { Пояс среднегорно-склоновый, дубовых, можжевелово- } \\
\text { дубовых и смешанных широколиственных лесов }\end{array}$ & 287 & 1133 & 846 & 602,9 & 589 & 0,55 \\
\hline $\begin{array}{l}\text { Пояс среднегорно-склоновый, буковых, буково-грабовых, сме- } \\
\text { шанных широколиственных лесов }\end{array}$ & 233 & 1500 & 1267 & 773,1 & 749 & 0,82 \\
\hline \multicolumn{7}{|c|}{ Зона яйлинских плато, горных лугов и горной лесостепи } \\
\hline Пояс лесных и лугово-лесостепных плато & 419 & 1308 & 889 & 916,7 & 924 & 0,58 \\
\hline Пояс луговых и лугово-лесных плато & 456 & 1531 & 1075 & 1189,2 & 1228 & 0,70 \\
\hline \multicolumn{7}{|c|}{$\begin{array}{c}\text { Зона южного макросклона гор, дубовых, сосновых и } \\
\text { смешанных широколиственных лесов }\end{array}$} \\
\hline $\begin{array}{l}\text { Пояс низкогорно-склоновый дубовых и смешанных широко- } \\
\text { лиственных лесов }\end{array}$ & 41 & 949 & 908 & 385,1 & 377 & 0,59 \\
\hline $\begin{array}{l}\text { Пояс среднегорно-склоновый, дубовых, сосновых и смешан- } \\
\text { ных широколиственных лесов }\end{array}$ & 115 & 1465 & 1350 & 601,2 & 561 & 0,87 \\
\hline $\begin{array}{l}\text { Среднегорный пояс буковых и смешанных широколиственных } \\
\text { лесов }\end{array}$ & 214 & 1485 & 1271 & 903,6 & 897 & 0,82 \\
\hline
\end{tabular}

Наиболее мелкой таксономической единицей, рассматриваемой в данной работе, являются ГМ. В пределах ГМ значения абсолютной высоты значительно варьируются как пределах ЛУ, так и в пределах ЛЗ и ЛП / ЛЯ. Учитывая тот факт, что в пределах КП выделяются 124 группы местностей, их статистические характеристики представлены картографическими материалами. На рисунке 3 представлены: минимальные и максимальные значения, амплитуда значений, средние значения высоты, медиана значений и относительная ширина факторной амплитуды в пределах ГМ.

При укрупнении таксономических единиц ландшафтной организации территории КП можно отметить, что сужение факторных амплитуд на более мелких таксономических единицах выражено слабо и в некоторых моментах вообще отсутствует. Это говорит о том, что при одинаковой факторной амплитуде либо формируются различия в положении таксономической единицы вдоль градиента фактора, либо существует более мощный фактор, который оказывает воздействие на формирование таксономической единицы ландшафта.

Согласно [Подгородецкий, 1988], значения абсолютных отметок высот на территории Крымского полуострова колеблются от 0 до 1545 м. Полученные в работе данные о значениях абсолютных высот в пределах КП незначительно отличаются от приведённых в литературе. Стоит отметить, что ошибки измерения как абсолютных значений, так и ширины факторной амплитуды при использовании модели SRTM составляют менее $1 \%$. Это частично подтверждается в работе [Карионов, 2010], где указывается, что точность данных SRTM соответствует топографическим картам масштаба 1:50000. Данное утверждение справедливо и для проводимого исследования.

Исследованию абсолютных высот ландшафтов КП посвящено незначительное количество работ. В большинстве из них анализируются взаимосвязи абсолютных высот и компонентов ландшафта на различных масштабах исследования [Плугатарь и др., 2020; Позаченюк, Табунщик, 2014; Позаченюк, Петлюкова, 2016; Бондаренко, Михайлов, 2016]. Отдельно стоит отметить работы [Современные ландшафты ..., 2009; Позаченюк, 1999], в которых приводится довольно подробная характеристика абсолютных высот ландшафтов КП. 
В пределах гидроморфного ЛУ абсолютные высоты изменяются от -6 до 208 м, плакорного ЛУ — от -13 до 186 м, низкогорного ЛУ — от -8 до 1047 м и среднегорного ЛУ — от 1 до 1531 . Полученные данные существенно отличаются от приводимых ранее в литературе. Так, в работе [Современные ландшафты ... , 2009, С. 166] указывается, что в пределах гидроморфного ЛУ значения абсолютных высот изменяются от 0 до 40 м, плакорного ЛУ — от 40 до 190 м, низкогорного ЛУ — от 0 до 700 м и среднегорного ЛУ — от 200 до 1500 м. Однако далее в тексте [Современные ландшафты ... , 2009] указывается, что в пределах ГЛУ высоты изменяются от 0 до 30-40 м [Современные ландшафты ... , 2009, С. 165], в пределах ПЛУ — от 30-40 до 160-180 м [Современные ландшафты ... , 2009, С. 168], в пределах НЛУ — от «побережья до 500-600 м».

В работе [Позаченюк, 1999, С. 21] указывается совершенно другая амплитуда значений высоты: для плакорного ЛУ - от 40 до 150 м, низкогорного ЛУ — от 0 до 600 м и среднегорного ЛУ — от 0 до 1500 м. Таким образом, можно утверждать, что на данный момент значения абсолютных высот ЛУ КП не установлены.

Полученные данные позволяют высказать предположение, что в работах [Современные ландшафты ... , 2009; Позаченюк, 1999] приводятся ошибочные данные об абсолютных высотах. Наше предположение подтверждается следующими фактами: визуальный анализ ландшафтной карты (рис. 3) указывает на то, что в работе [Современные ландшафты ..., 2009, С. 166] приводятся ошибочные данные, так как отчётливо видно, что территория плакорного ЛУ граничит по побережью как с Чёрным, так и Азовским морями и на этих границах минимальные высоты плакорного ЛУ не могут достигать 40 м; также, если проанализировать пространственное положение среднегорного ЛУ, отчётливо видно, что он имеет выход к Чёрному морю и тем самым должен иметь минимальные значения абсолютных высот, начиная с 0 метров над уровнем моря, а никак не с 200 м.

Здесь также стоит отметить, что в работе [Современные ландшафты ..., 2009] иногда употребляется термин «предгорный ЛУ» вместо термина «низкогорный ЛУ». Если рассмотреть теоретическую работу Г. Е. Гришанкова [Гришанков, 1972], где он впервые сформулировал научное определение ЛУ, то в ней использован термин «предгорный ЛУ». Таким образом, в работе [Современные ландшафты ..., 2009] наблюдается терминологическая путаница, т. к. неясно, как появился термин «низкогорный ЛУ» и каково его содержание, есть ли различия между терминами. Помимо этого, в работе [Гришанков, 1972] автор указывает на тот факт, что в пределах материков ПЛУ имеют абсолютные отметки от 50 до 1000 м, а СЛУ — от 400 до 1200 м. Это утверждение, противоречащее полученным нами данным для КП, можно объяснить доказательствами, приведёнными выше. В то же время стоит отметить, что такие расхождения могли возникнуть из-за того, что в работе [Гришанков, 1972] теоретические построения выполнены для глобального масштаба (на уровне материка), а в данном исследовании использован региональный масштаб, что позволяет детализировать теоретические данные.

Характеристика абсолютных высот ЛЗ КП приводится в работах [Современные ландшафты ..., 2009; Позаченюк, 1999]. Учитывая тот факт, что ГЛУ и ПЛУ имеют каждый в своем составе только одну ЛЗ, приведённая выше информация для ЛУ будет справедлива и для ЛЗ. Стоит, однако, заметить, что в работах [Современные ландшафты ..., 2009; Позаченюк, 1999] употребляется термин «природная зона» или просто «зона». К тому же названия ЛЗ, слагающих ЛУ, в тексте работ [Современные ландшафты ..., 2009; Позаченюк, 1999] и в легенде ландшафтной карты Г. Е. Гришанкова, приводимой в работе [Современные ландшафты ..., 2009], существенно различаются, что вызывает определённые трудности с пониманием названия объекта исследования. Так, в легенде ландшафтной карты Г. Е. Гришанкова [Современные ландшафты ... , 2009, С. 621-628] указывается, что ГЛУ состоит только из одной зоны «низменных недренированных и слабодренированных аккумулятивных и денудационных равнин 


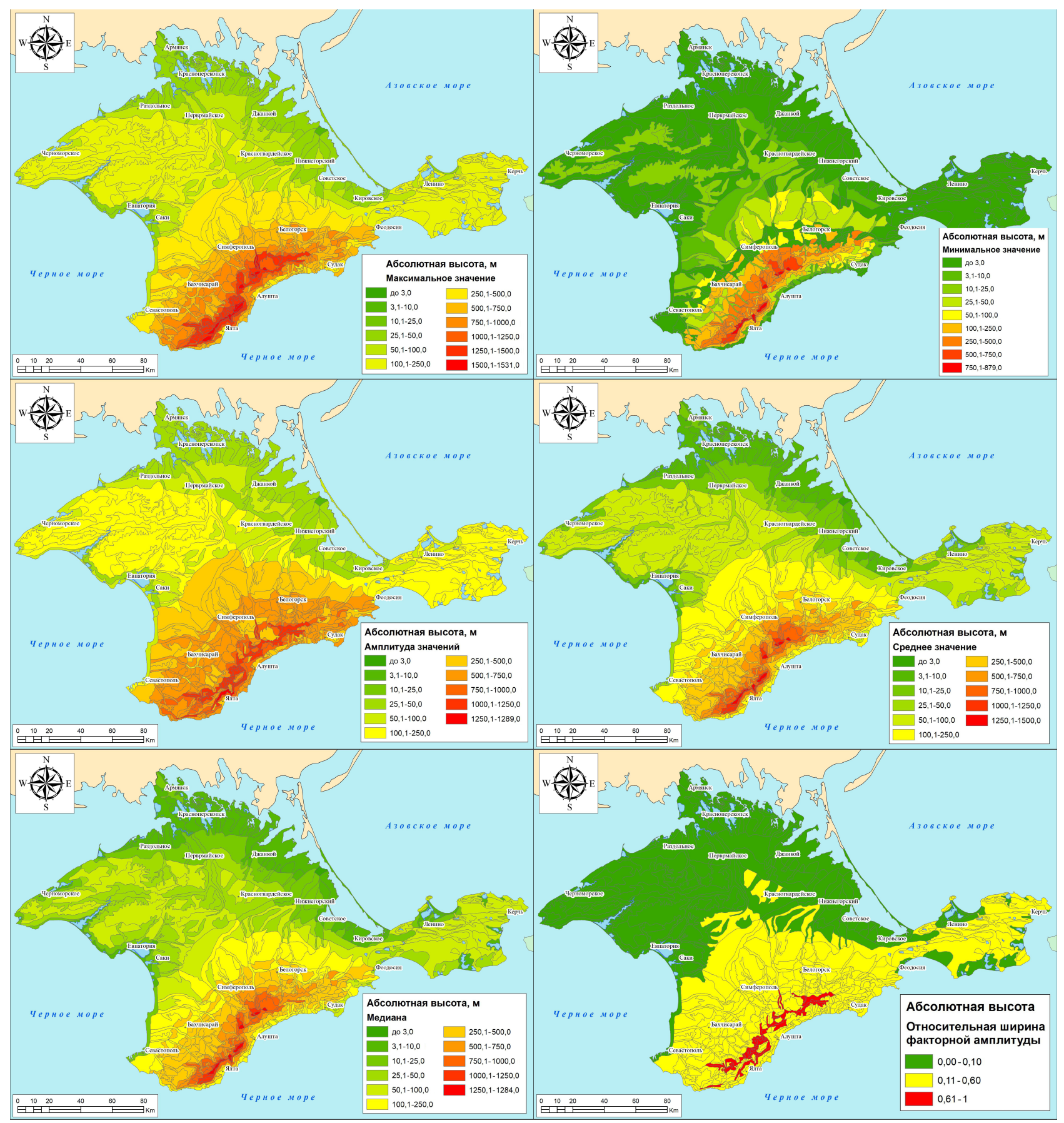

Рис. 3. Минимальные и максимальные значения, амплитуда значений, средние значения, медиана значений и относительная ширина факторной амплитуды по фактору «абсолютная высота, м» в пределах групп местностей Крымского полуострова (составлено автором) 
с типчаково-ковылковыми, полынно-типчаковыми, полынно-житняковыми степями в комплексе с галофитными лугами и степями», в то время как в тексте, помимо этой зоны, указывается и природная зона «полупустынных реликтово-бореальных степей в комплексе с галофитным и полусубтропическими степями полупустынного типа» [Современные ландшафты ... , 2009, С. 166]. Однако, несмотря на это, очевидно, что подразумеваются одни и те же объекты.

Полученные данные о характеристике ЛЗ отличаются от ранее опубликованных в работах других авторов. В таблице 2 указывается, что в пределах НЛУ зона предгорных аккумулятивных, останцово-денудационных и структурных денудационных равнин и куэстовых возвышенностей с разнотравными степями, кустарниковыми зарослями, лесостепью и низкорослыми дубовыми лесами имеет отметки высот от -8 до 766 м, а зона южного макросклона гор, полусубтропических дубовых, фисташково-дубовых, можжевелово-сосновых лесов и шибляковых зарослей имеет отметки высот от -2 до 1047 м. А в работе [Современные ландшафты ... , 2009, С. 171] указывается, что «низкогорный уровень занимает на северном и северо-западном макросклоне гор полосу на высоте от 100 до 700 м (предгорье), на южном (юго-восточном) 一 от побережья до 500-600 м». В пределах СЛУ зона горных лугов и горной лесостепи имеет значения абсолютных высот от 419 до 1531 м, в то время как в [Современные ландшафты ... , 2009, С. 402] указывается, что абсолютные высоты изменяются от 600 до 1500 м.

Полученные значения высоты в пределах ЛП и ЛЯ КП также значительно отличаются от данных, приводимых в работе [Современные ландшафты ... , 2009], однако полностью значения абсолютных высот приведены только для ЛП ГЛУ (таблица 4).

Таблица 4

Сравнение расчётных данных об абсолютных высотах в пределах поясов ГЛУ

\begin{tabular}{|l|c|c|}
\hline \multicolumn{1}{|c|}{ Ландшафтный пояс } & \multicolumn{2}{|c|}{ Абсолютная высота, м } \\
\cline { 2 - 3 } & Расчётные данные & по [1] \\
\hline $\begin{array}{l}\text { Пояс прибрежных недренированных низменностей, пляжей и кос } \\
\text { с галофитными лугами, солончаками и сообществами псаммофитов }\end{array}$ & от -6 до 208 & до $8-10$ до 20 \\
\hline $\begin{array}{l}\text { Пояс аккумулятивных и денудационных недренированных и сла- } \\
\text { бодренированных низменностей с полынно-типчаковыми, полынно- } \\
\text { житняковыми и ковыльно-типчаковыми степями }\end{array}$ & от -6 до 167 & от 15 до 40 \\
\hline $\begin{array}{l}\text { Пояс аккумулятивных и денудационных слабодренированных } \\
\text { равнин с ковыльно-типчаковыми и полынно-типчаковыми степями }\end{array}$ & от -4 до 88 & от 15 до 40 \\
\hline $\begin{array}{l}\text { Пояс аккумулятивных дренированных и слабодренированных } \\
\text { низменностей с ковыльно-типчаковыми степями в комплексе } \\
\text { с ковыльно-разнотравными степями }\end{array}$ & от 1 до 51 & \\
\hline
\end{tabular}

Стоит отметить также тот факт, что в самом описании ЛП иногда встречаются неточности. Так, в [Современные ландшафты ..., 2009, С. 231] утверждается, что «пояс аккумулятивных и денудационных недренированных и слабодренированных низменностей с полыннотипчаковыми, полынно-житняковыми и ковыльно-типчаковыми степями ... расположен на высоте от 8-10 до 20 м над уровнем моря», однако далее отмечается, что в юго-западной части Керченского полуострова абсолютные высоты достигают 50-80 м, а это, в свою очередь, противоречит вышесказанному. 
Поскольку в работах [Современные ландшафты ... , 2009; Позаченюк, 1999] не приводится никаких данных о выборке значений, кроме минимальных и максимальных значений, то полное сравнение с полученными нами данными провести довольно затруднительно. Так, предположение о том, что данные об абсолютных высотах, представленные в [Современные ландшафты ... , 2009], близки к средним и медианным, не подтверждается расчётными данными.

В работе [Закаличная, Мельничук, 2020] для анализа высот в пределах Симферопольского района Республики Крым использована цифровая модель рельефа Advanced Land Observing Satellite-1 World 3D Topographic data (ALOS AW3D), Version 2.1, визуальное сравнение которой c SRTM показывает схожесть горизонталей, однако сравнить данные, представленные в [Закаличная, Мельничук, 2020, С. 203], с полученными данными для ландшафтных единиц не представляется возможным.

Подробная характеристика абсолютной высоты в пределах групп местностей (окоёмов) в литературе ранее не приводилась и в данной работе выполнена впервые.

Относительные факторные амплитуды показывают долю факторного пространства, которое занимает та или иная таксономическая единица. ГЛУ и ПЛУ по отношению к фактору абсолютной высоты являются мезофакторными, в то в время как НЛУ и СЛУ - эврифакторными. При этом стоит учесть тот факт, что полученные значения для ГЛУ, ПЛУ и НЛУ близки к пограничным и в силу значительных площадей ЛУ на более низких таксонах ландшафтной организации имеют тенденцию к уменышению значений относительной факторной амплитуды. Так, среди ЛП ГЛУ два пояса имеют узкий интервал значений относительной факторной амплитуды (стенофакторные), а два — средний (мезофакторные), ЛЯ ПЛУ — мезофакторные, а вот уже ГМ ГЛУ и ПЛУ практически все являются стенофакторными с узкими амплитудами. Среди ландшафтных поясов НЛУ только один пояс южного макросклона Крымских гор относится к эврифакторным, а остальные - мезофакторные. В пределах СЛУ преобладают эврифакторные ЛП. Таким образом, отчётливо прослеживается тенденция роста относительных значений факторных амплитуд при увеличении абсолютных высот с севера на юг на территории Крымского полуострова.

Обобщая вышеизложенное, можно сказать, что с помощью современных методов исследования получены новые данные о высоте таксономических единиц по карте Г. Е. Гришанкова. Полученные значения наиболее полно отражают значения абсолютных высот в пределах ландшафтов КП.

\section{Выводы}

Получены новые, а также уточнены и дополнены количественные характеристики положения различных таксономических единиц ландшафтов Крымского полуострова в пространстве фактора «абсолютная высота, м». Установлено, что в ряде работ ранних лет приводятся неполные и разрозненные данные об абсолютной высоте ландшафтов Крымского полуострова. Проделанный анализ показывает, что распределение таксономических ландшафтных единиц на территории КП тесно связано с фактором абсолютной высоты рельефа и становится менее выраженным по мере укрупнения таксономических единиц - от ландшафтного уровня до группы местностей. В то же время видно, что рельеф отчётливо различается в пределах ГЛУ - ПЛУ и НЛУ - СЛУ. 


\section{Список литературы}

1. Берг Л. С. Предмет и задачи географии. Что такое география? / В. Семёнов-Тян-Шанский. Петроград : Тип. М. М. Стасюлевича, 1915. - С. 471.

2. Бондаренко М. А., Михайлов В. А. Геоморфологические факторы формирования высотной поясности растительного покрова юго-восточного склона Бабуган-яйлы (Крымский полуостров) // Современные научные исследования и инновации. - 2016. - № 7 . URL: https://web.snauka.ru/issues/2016/07/70250 (дата обращения: 19.09.2021).

3. Вопросы истории развития рельефа и ландшафты Азербайджанской ССР / ред.: Б. А. Антонов, Б. А. Будагов. - Баку : Элм, 1976. - 200 с. - (Труды Института географии / Акад. наук АзССР ; т. 16).

4. Гришанков Г. Е. Ландшафтные уровни материков и географическая зональность // Известия Академии наук СССР. Серия географическая. - 1972. - № 4. - С. 3-18.

5. Закаличная O. В., Мельничук А. Ю. Морфометрические характеристики рельефа агроландшафтов Симферопольского района Республики Крым // Известия высших учебных заведений. Геодезия и аэрофотосъёмка. - 2020. - Т. 64, № 2. - С. 200-209. - https://doi.org/10.30533/0536101X-2020-64-2-200-209

6. Исаченко А. Г. Ландшафтоведение и физико-географическое районирование. - Москва : Высш. шк., 1991. - 366 с.

7. Карионов Ю. И. Оценка точности матрицы высот SRTM // Геопрофи. - 2010. - № 1. - С. $48-51$.

8. Морфологическая структура географического ландшафта / Моск. гос. ун-т им. М. В. Ломоносова ; под ред. Н. А. Солнцева. - Москва : [б. и.], 1962. - 54 с.

9. Мурашова Е. Г. Рельеф и пространственная дифференциация ландшафтов Зейско-Буреинской равнины. - Благовещенск : Изд-во Дальневост. гос. аграр. ун-та, 2013. - 200 с.

10. Плугатарь Ю. В., Коба В. П., Новицкий М. Л., Папельбу В. В., Пиеничников Н. А. Высотная зональность почвенных условий горных ландшафтов Юго-Восточного Крыма // Земледелие. 2020. - № 8. - C. 10-15. - https://doi.org/10.24411/0044-3913-2020-10802

11. Плюснин В. М. Ландшафтный анализ горных территорий. - Иркутск : Изд-во Ин-та географии CO PAH, 2003. - $256 \mathrm{c}$.

12. Подгородеикий П. Д. Крым: природа. - Симферополь : Таврия, 1988. - 191 с.

13. Позаченюк E. А. Ландшафтно-типологическая структура Крыма // Вопросы развития Крыма : науч.-практ. дискус.-аналит. сб. / отв. ред.: Л. Г. Апостолов, А. И. Дулицкий. - Симферополь : Сонат, 1999. - Вып. 11 : Биологическое и ландшафтное разнообразие Крыма: проблемы и перспективы. - С. 20-25.

14. Позаченюк E. А., Петлюкова Е. А. ГИС-анализ морфометрических показателей рельефа центрального предгорья Главной гряды Крымских гор для целей ландшафтного планирования // Учёные записки Крымского федерального университета имени В. И. Вернадского. География. Геология. - 2016. - Т. 2, № 2. - С. 96-113.

15. Позаченюк E. А., Табунщик B. А. Построение ниш ландшафтов Крымского Присивашья (в пределах Джанкойского района АР Крым) // Геополитика и экогеодинамика регионов. 2014. - T. 10, № 1. - С. 322-328.

16. Рельеф и ландшафты : [сб. ст. : к 90-летию И. С. Щукина] / под ред. Н. А. Гвоздецкого, А. И. Спиридонова. - Москва : Изд-во Моск. ун-та, 1977. - 208 с.

17. Современные ландшафты Крыма и сопредельных акваторий / Респ. ком. АР Крым по охране окружающей природ. среды, Таврич. нац. ун-т им. В. И. Вернадского ; ред. Е. А. Позаченюк. Симферополь : Бизнес-Информ, 2009. - 672 с.

18. Солнцев Н. А. Учение о ландшафте : избр. тр. - Москва : Изд-во МГУ, 2001. - 383 с.

19. Структурно-региональный анализ рельефа и ландшафтов : межвуз. сб. науч. тр. / Воронеж. гос. пед. ин-т ; редкол.: Н. С. Бевз [и др.]. - Воронеж : ВГПИ, 1984. - 95 с. 


\section{LANDSCAPES DISTRIBUTION OF THE CRIMEAN PENINSULA BY ABSOLUTE ALTITUDES}

Tabunshchik V. A., Kelip A. A., Andronchik Ya. O.

A. O. Kovalevsky Institute of Biology of the Southern Seas of RAS, Sevastopol, Russian Federation, e-mail: tabunshchyk@ya.ru

In the article quantitative data on the absolute elevation of the relief within the taxonomic units of the landscapes of the Crimean Peninsula are provided. It was found that in a number of works of the early years, incomplete and scattered data on the absolute altitudes of the landscapes of the Crimean Peninsula are given. It is established that the value of the absolute altitudes of the relief is a factor that has a great influence on the differentiation of the landscape sphere of the Crimean Peninsula at high taxonomic units and gradually, the influence of this factor is smoothed out when allocating smaller taxonomic units.

Keywords: landscape, the Crimean Peninsula, relief, absolute altitudes, factor.

\section{Сведения об авторах}

Табунщик

Владимир

Александрович

Келип

Андрей

Алексеевич

Андрончик

Ярослав

Олегович младший научный сотрудник ФГБУН ФИЦ «Институт биологии южных морей им. А. О. Ковалевского РАН», tabunshchyk@ уa.ru

младший научный сотрудник ФГБУН ФИЦ «Институт биологии южных морей им. А. О. Ковалевского РАН», kelip@ibss-ras.ru

заместитель директора по административно-хозяйственной деятельности ФГБУН ФИЦ «Институт биологии южных морей им. А. О. Ковалевского РАН», zamfin@ibss-ras.ru

Поступила в редакцию 10.08.2021 2. Принята к публикации 11.10.2021 2. 